\title{
EDITORIAL: Melanesian media freedom
}

-HE SOVEREIGN states of Melanesia are countries where the yoke of colonialism and struggles for independence are still within living memory. There are territories within Melanesia where the questions and complexities associated with achieving self-determination are very much live issues. In West Papua, this issue is one over which blood continues to be spilt. As these countries, and the communities within them, grapple with political-economic and technical shifts, the need for independent journalism is self-evident. However, journalists, editors, publishers and media owners face a barrage of challenges to their ability to operate free from repression or coercion by those who wield power in their societies. Some of these challenges are overt and can extend to threats or physical intimidation. Others are more subtle but no less pervasive and damaging. They lead to a narrowing of the media landscape, the loss of talented professionals to other areas, the rise of self-censorship, and more.

The establishment and entrenchment of democratic culture in Melanesia is a work in progress. Recognising the threats to media freedom and supporting industry professionals in navigating and countering them is fundamental to furthering this endeavour.

This special issue of the Pacific Journalism Review draws upon a growing need to discuss media freedom in Melanesia - a distinct sub-region of Oceania that comprises Fiji, Vanuatu, New Caledonia, Solomon Islands, Papua New Guinea, the Autonomous region of Bougainville, West Papua and the Torres Strait Islands. The articles in this collection are the culmination of a series of wide-ranging discussions bringing journalists from these countries together in Brisbane, Australia, under the banner of the Melanesia Media Freedom Forum (MMFF) - a gathering convened in response to increasing media repression in Melanesia, to find avenues of future-proofing press freedom, though transnational regional co-operation and knowledge-sharing among journalists, editors, publishers, press-freedom advocates and journalism scholars.

In editing this special issue, we are mindful of the ongoing media repression in the Melanesian sub-region - in particular in Fiji, Vanuatu, Papua New Guinea and West Papua. In his article on press freedom in Fiji, Papua New Guinea, Solomon Islands and Vanuatu, Shailendra Singh notes 'how little control the media have over both external and internal threats, and how stakeholder support is needed to overcome some of the issues', while Marie M'balla-Ndi Oelgemöller and Levi Obijiofor note increasing threats to media freedom and abuse of journalists when discussing challenges they faced researching the impact of national security legislation.

The legacy of the former Fijian military dictatorship continues to maintain 


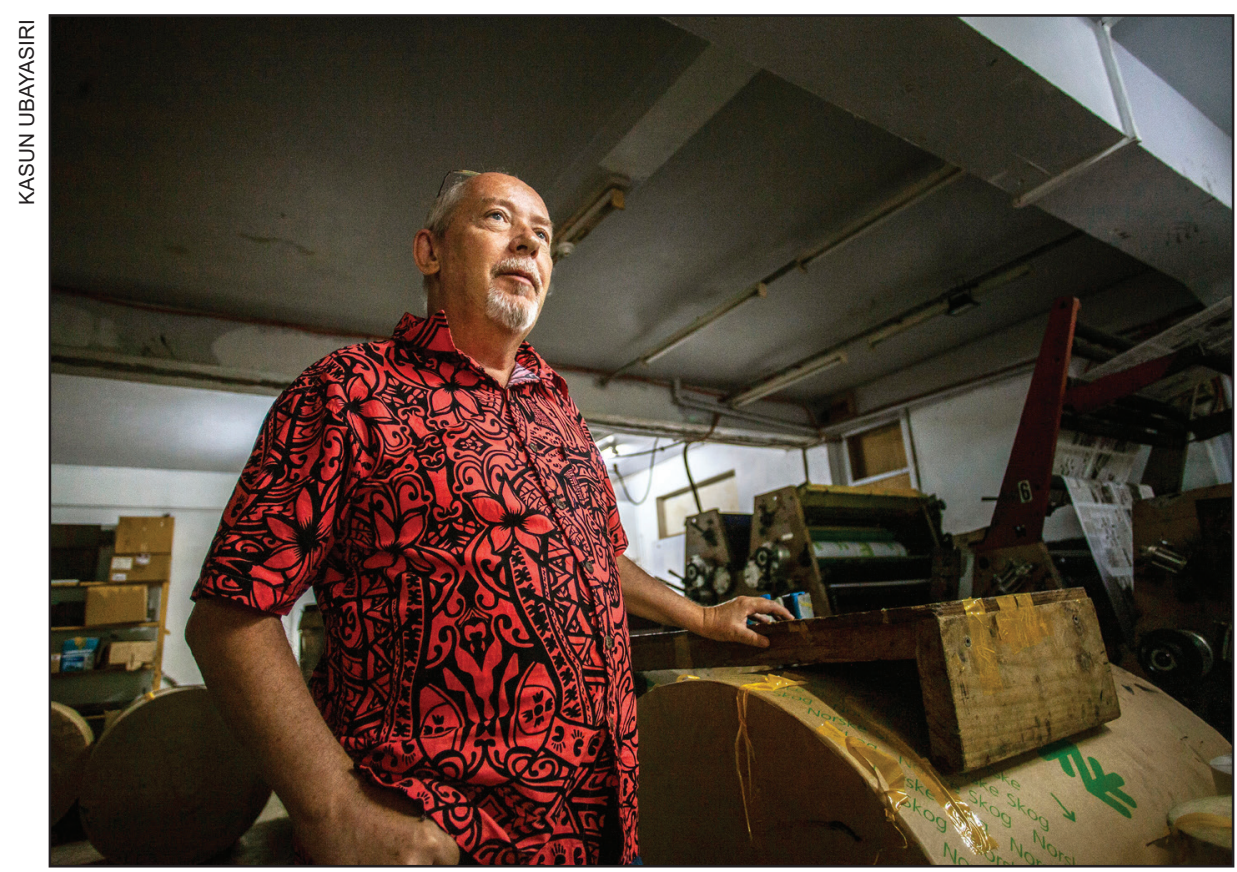

Figure 1: Former Vanuatu Daily Post media director Dan McGarry: A Vanuatu government attempt to deny him re-entry to his home country of 16 years heralds a troubling future for press freedom.

a stranglehold on the local press under Prime Minister Voreqe Bainimarama, fostering a culture of self-censorship. The hostile media environment under which the Fijian press had operated since the introduction of the repressive $\mathrm{Me}$ dia Industry Development Decree in 2010, which became an Act of Parliament in 2015, has further paved the way for even more insidious control through the establishment of a state-controlled Media Industry Development Authority. The MIDA's intimidation, coupled with the use of sedition laws to silence journalists, as in the case of the three Fiji Times journalists in 2018, has further raised the cost of independent journalism in Fiji.

The Vanuatu government attempted to deny Vanuatu Daily Post's Dan McGarry permission to re-enter the country in 2019 after he participated in the Melanesia Media Freedom Forum. McGarry was the former media director of the Vanuatu Daily Post, the country's only daily newspaper. This heralds a troubling future for press freedom. McGarry's claim that the Prime Minister had personally summoned and reprimanded him for alleged 'negative' coverage is even more worrying and indicative of the extrajudicial and arbitrary nature of such repression.

The election of Prime Minister James Marape in Papua New Guinea, in mid-2019, may have removed the dictatorial grip of former Prime Minister Peter O'Neill that saw countless violations of press freedom from direct threats, 
intimidations, and attempts to bribe journalists to prosecutions and media censorship; but media freedom in Papua New Guinea remains endangered. With the country's two leading dailies owned by overseas multi-nationals-PNG Post Courier by Australian-US media tycoon Rupert Murdoch's News Corp, and The National, by the Malaysian logging company Rimbunan Hijau, journalists continue to lack real agency in reporting issues that are important to the local communities. Rimbunan Hijau has been particularly restrictive in sanctioning vital environmental reportage. The government's attempt to suspend senior Papua New Guinean journalist and EMTV's Lae city bureau chief Scott Waide for airing a story critical of the government in 2018 (see the Fred Wesley profile) and the sacking of Neville Choi under the pretext of 'non-compliance' is further evidence of this worrying trend.

Press freedom in Indonesian-occupied West Papua continues to deteriorate. Since Indonesia's occupation in 1963, nearly all foreign media have been banned from entering West Papua. A handful of local journalists like Jubi editor Victor Mambor continue to work under challenging working conditions, walking a thin line between compliance and press freedom. However, this special issue of PJR is also about acknowledging positive developments in press freedom, however fleeting. It aims to identify new opportunities delivered through long fought for political change - the overwhelming election result in favour of independence from Papua New Guinea offers fresh hope for independent and robust journalism in Bougainville.

Bridget Backhaus notes external threats to media freedom are not limited to government pressures, as she points out 'funding requirements of the global aid industry means that Melanesian journalists may find themselves under pressure to conform to dominant narratives of development in order to appease donors and training providers'. This reliance on outside funding models can lead to media coverage that 'paints a misleading picture of the way things are, instead of showing donors and international interests what they want to see' and Backhaus critically considers approaches to development communication that may impact the way Melanesian media workers work in this environment.

We begin this edition of PJR with David Robie's outline of some of the key challenges for Melanesian media freedom. Presented in his keynote presentation at the Forum, Robie focuses on a number of central developments in the region's media theatre - climate crisis, the impact of the rise of social media platforms, internet freedom and the growing prevalence of fake news. Amanda Watson's commentary on mobile phone access and equity in Papua New Guinea and the government decisions to impose tighter regulations that may exclude disadvantaged communities accessing mobile communication highlights the impediments to the digital revolution in the region.

Several authors, including David Robie, have also noted how Australia has 


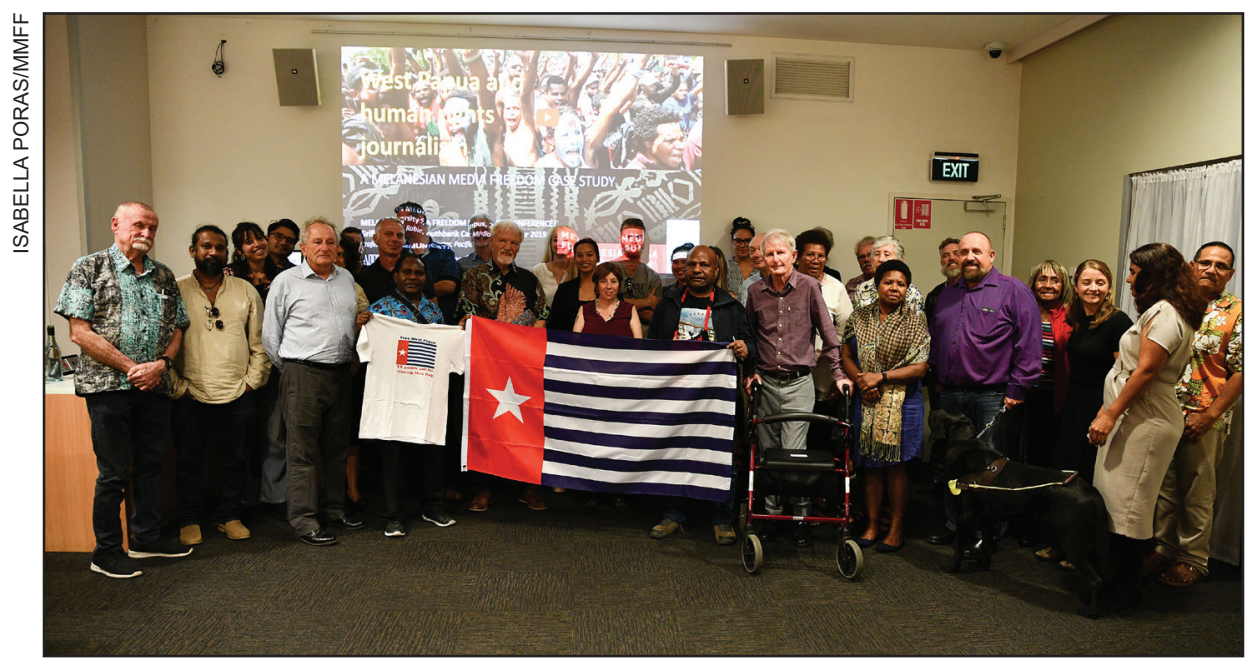

Figure 2: Participants at the Melanesia Media Freedom Forum pre-conference on 28 October 2019. Veteran Papua New Guinea and Pacific correspondent of the ABC Sean Dorney is in the centre.

systematically distanced themselves from their closest neighbours in the region. Lee Duffield reminds us how "coverage of Papua New Guinea in Australian media has been a source of resentment and dissatisfaction among academic writers and journalists within PNG and in Australia, and PNG activists and political leaders since the former Territory's independence in 1975'. The exception, Duffield argues, was acclaimed journalist Sean Dorney's ground-breaking reportage of the Melanesian sub-region for the Australian Broadcasting Corporation (ABC) as Auntie's Port Moresby correspondent. He notes how Dorney was an institution, providing quality ongoing coverage of the Pacific from PNG contrasted against the disinterest from Australia's commercial press and television - a void. It is left to the ongoing contributions of the non-Murdoch press such as ABC, SBS, NITV and the 'new media' Guardian Australia providing essential coverage of the region.

This special issue of the journal also comes at a time of renewal and hope in the region, with the Bougainville and New Caledonia's independence referenda bringing the West Papuan independence issue into even sharper focus. Robie's keynote lecture speaks to West Papua, acknowledging it is undergoing a vitally important self- determination issue that if left unresolved threatens the security of the region. This concern for the crisis in West Papua remains high with journalists and academics alike. This is evidenced by the number of submissions for this special edition about West Papua. Researcher Pelagio Da Costa Sarmento collaborates with editor-in-chief of the West Papuan media outlet Tabloid Jubi Victor Mambor, in producing an in-depth commentary detailing the limitations faced by local and international journalists highlighting West Papua's status as 
one of the most closed regions in the Reporters Without Borders Global Press Freedom Index. They describe how foreign journalists are hamstrung by intricate complexities of redtape in applying for a permit to come to West Papua where they are then closely monitored by security forces on arriving. Local journalists with legitimate news organisations regularly face threats to their safety and security. They also discuss how an increase in online media has seen fake news and disinformation campaigns threatening legitimate news outlets.

Presenting a different perspective about the impact of social media outside of West Papua, Jason Titifanue, Romitesh Kant and Glenn Finau argue social media is the antidote to West Papua's media oppression and growing 'solidarity for West Papua's self-determination is resulting in a heightened Pacific regional consciousness at the community level'. Ana Nadhya Abrar takes an intimate look at two West Papuan journalists and their relationship with human rights. Separating the journalist from the reporting, the author's interviews with the reporters suggest there is a weariness developing, fatigue if you will, around reporting ongoing human rights abuses and violations.

The special issue also focuses on several touchstone issues in the cultural landscape of the region's media. Faith Valencia-Forrester, Bridget Backhaus and Heather Stewart capture the panel discussions featuring female Melanesian journalists to analyse the unique challenges women reporters face in terms of representation and media freedom, in an inherently patriarchal society. Verena Thomas and Jackie Kauli's work, assisting human rights defenders in sharing their experiences around sorcery accusations and violence in Papua New Guinea, provide a rare glimpse of how the news media is navigating the intersect between human rights and traditional beliefs. In their contribution to this special edition, they examine the ethics of representation when it comes to reporting human rights abuses and violence and provide suggestions for alternative ways of reporting.

Pacific Journalism Review's associate editor Philip Cass contributes an article exploring climate change communication in Papua New Guinea, particularly with the use of the Tok Pisin language. The paper compares the situation in PNG with the use of Pidgin English in Nigeria and concludes that the Pacific's largest country faces an 'enormous challenge' in educating the grassruts about climate action best practice and engaging with communities.

Despite the trials, tribulations and complexities inherent in producing independent and meaningful journalism in the Melanesian sub-region, this special joint issue of the journal and the Melanesia Media Freedom Forum is one of hope. It is a testament to the resolve and commitment of the region's journalists, media academics and communications sector stakeholders in striving to produce independent and robust Fourth Estate journalism and media content that speak truth to power, animate democracy and give voice to the voiceless. It is the start of a new journey for a stronger press and a united front against tyranny. 
This commitment is echoed in the words of the Fiji Times editor-in-chief, Fred Wesley, who writes of the need for solidarity, and how he, along with his colleagues, Victor Mambor from West Papua, Scott Waide of Papua New Guinea, and Dan McGarry in Vanuatu, are holding firm to the banner of press freedom in Melanesia in the face of overwhelming forces. As Wesley notes

When you start reaching out, talking to others in the region, you find that you are not actually alone in this. The experiences are similar. The intensity varies, but the take-home for me is that nobody should be alone to handle their problems on their own.

We hope this special edition of $P J R$ goes in some small way to reaching out to those who couldn't make it to the forum, to let you know that while your media may not be free, you are not alone.

\section{KASUN UBAYASIRI}

FAITH VALENCIA-FORRESTER

TESS NEWTON CAIN (Chair, MMFF, 2019)

Melanesia Media Freedom Forum

Griffith University

www.griffith.edu.au/melanesian-media-freedom-forum

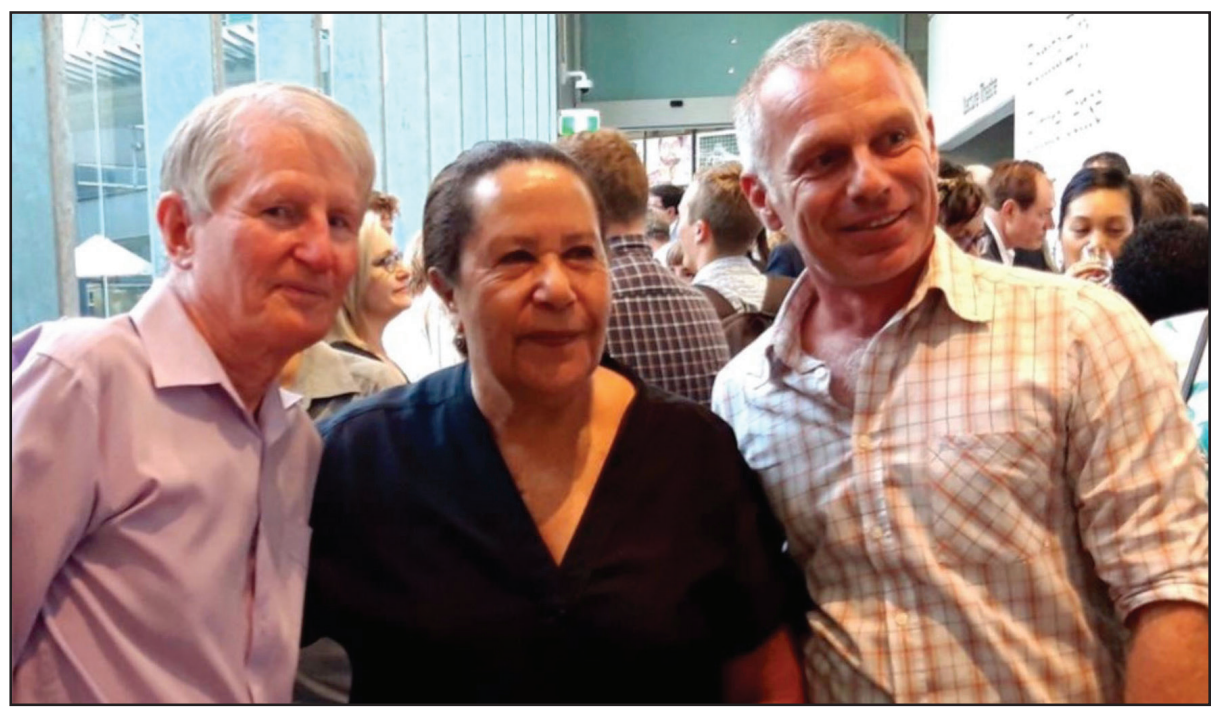

Figure 3: Sean Dorney, the doyen of Pacific journalism, pictured with Pacific Islands Forum Secretary-General Meg Taylor and SBS World News reporter Stefan Armbruster at the 2019 MMFF symposium in Brisbane. Dorney was named an Officer of the Order of Australia in the 2020 Queen's Birthday Honours for his 'service to the broadcast media as a journalist, and as an author'. 
UR unthemed section of this edition of Pacific Journalism Review also begins with Melanesia, specifically West Papua. The first article in our doublebarrelled Frontline department - dedicated to journalism and creative practice as research edited by Professor Wendy Bacon and Nicole Gooch-features Belinda Lopez with an exegesis and narrative based on her 2020 ABC radio documentary profiling women advocates for West Papuan freedom, \#Illridewithyou, West Papua. As Lopez, explains, West Papua is poorly understood by Australians - and New Zealanders - in spite and the human rights upheaval across both West Papua and Indonesia in 2019 so she set out on a long-form journalism project that could 'explore the roots of this discontent'. She invokes the work of Haitian anthropologist Michel-Rolph Trouillot, Papuan writer and an anthropologist Benny Giay and Australian author, journalist and filmmaker Chris Nash (What is journalism? The arts and politics of rupture, 2016) on the affective mode on her journey. She concludes:

I argue that effect is important in reversing silences on underreported issues, such as those that take place in West Papua... The audio documentary allows for an affective mode, as opposed to a statistical representation of deaths and crimes often found in reporting about West Papua.

In the second Frontline article, Professor Annie Goldson debates creative practice as a research methodology from a New Zealand research environment perspective in the contexts of both her own trailblazing documentary career within a university with such acclaimed feature film titles as Brother Number One, He Toki Huna: New Zealand in Afghanistan and Kim Dotcom: Caught in the Web, and the Performance-Based Research Fund (PBRF) framework. She argues:

The now-common usage of the term [creative-practice] ... is in part a greater recognition within the academy that cultural production can be research-rich providing 'new knowledge' to its respective fields. But its recognition has also been useful to the institutions themselves.

The Special Report section features an article by University of the South Pacific's Pacific Centre for Environment and Suistainable Development (PaCE-SD) director and joint Nobel Peace Prize-winner Professor Elisabeth Holland addressing the simultaneous challenge of Tropical Cyclone Harold and the global COVID-19 pandemic faced by four island nations, Fiji, Solomon Islands, Tonga and Vanuatu. She notes how Prime Minister Bainimarama called upon Fiji to 'honour the power of the spirit of vei lomani - that profound sense of love and devotion to the protection of our people'. With the late 2019 measles epidemic in Fiji, Samoa (death toll 83), Tonga and American Samoa fresh in their minds, Pacific leaders were determined to lead by example to prevent coronavirus devastation in their countries. 
Also addressing the challenges of COVID-19 is Arjun Rajkhowa, who argues that a more sophisticated approach is needed to negotiating gaps in emerging communication and information uncertainties of a pandemic of this magnitude is needed. Also, the media coverage of health crises in Australian and New Zealand can have a significant impact on the wider Pacific region.

Two Indonesia-based UNESCO lecturers Gilang Desti Parahita and Zainuddin Muda Monggilo with PR2Media's Engelbertus Wendratama analyse the success and challenges of multimedia journalism training in Timor-Leste, a country that is seeking to build a sound mediascape for the future. In New Zealand, Francine Tyler provides a compelling history and critique of the country's unique name suppression laws. While a new law due to take effect in August 2020 addresses some of the issues, she laments that after erosion for many years the 'raft ... of suppressions' code will still impact on 'New Zealand's media in a way that is extremely unusual in comparison to other Western nations'.

Heading the Reviews section, is an intriguing and compelling analysis by former New Zealand Herald editor Jeremy Rees of the 1972 Commission of Inquiry report into the controversial sacking of the then New Zealand Listener editor Alexander MacLeod. The Listener is one of the icons of New Zealand magazine publishing and was among the host of titles axed with the sudden closure of Bauer Media's New Zealand operations during the COVID-19 lockdown in April 2020.

The pandemic has ushered in a host of publication and radio closures on both sides of the Tasman and the loss of hundreds of editorial jobs. But we should not totally despair. The 'new normal' is also creating many entrepreneurial and niche media opportunities. While the mass media market model may be dead, or dying, journalism is still very much alive.

A FINAL word. Many thanks to the countless people who have contributed much to this journal over the years as volunteers or in roles outside their core academic and media jobs. Now in its 26th year - an incredible milestone- $P a$ cific Journalism Review last year celebrated the addition of 17 years of research archives to its Tuwhera indigenous open access platform at Auckland University of Technology. All the articles from the journal's pioneering days at the University of Papua New Guinea (1994-1998) and University of the South Pacific (1999-2002) are now available to freely download. Thank you Donna Coventry and Luqman Hayes. No more paywalls - great news for Pacific researchers.

\section{DAVID ROBIE}

\section{Editor}

Pacific Journalism Review

www.pjreview.info 